\title{
Barth and Buddhism: A Theology of Prayer and Meditation in Christian and Buddhist Exchanges
}

\author{
David Thang Moe* \\ Asbury Theological Seminary, USA
}

Submission: November 14, 2017; Published: August 22, 2018

*Corresponding author: David Thang Moe, Asbury Theological Seminary, Wilmore, USA, Email: davidmoe83@gmail.com

\section{Introduction}

Prayer is central to the spiritual life of Christianity, so is meditation to Buddhism. Jesus and the Buddha are the important foci of their respective traditions about prayer and meditation ${ }^{1}$. Jesus teaches His disciples how to pray-this is what we call the Lord's Prayer (Matt. 6:9-13). Likewise, the Buddha teaches his disciples (sanga) how to meditate. The purpose of this paper is to compare the Christian practice of prayer and the Buddhist practice of meditation. In doing this, I would like to consult with Barth's Christian theology of prayer. The questions I raise in this paper are: what is a theological concept of prayer in the thought of Barth? What is a theological concept of Buddhist meditation? What are the goals of prayer and meditation? What are the convergences and divergences of Christian prayer and Buddhist meditation?

I will finish this paper by proposing the idea that the Buddhist practice of mediation is compatible with the Christian practice of prayer despite their divergences. From this follows, I will argue that a new understanding of Christian faith as an ontological and spiritual encounter with God and as a liberation creates the possibility of Christian prayer's compatibility with the Buddhist spiritual practice of meditation[1].

\section{Christian prayer in the theology of Barth}

In his Church Dogmatics III.3, Barth discusses faith, obedience and prayer as the threefold form of Christian identity and vocation. Barth does not treat prayer simply as the other of faith and obedience. He argues that "basically, faith is prayer, obedience too is prayer ${ }^{2}$. However, he believes we cannot do justice the distinctiveness of prayer if we simply think of it as the basic form of faith and obedience. When we think of prayer in this way, what is lacking is the center of prayer. For Barth, prayer is the center from

which the other two flow and to which the other two return. In this sense, I would like to regard prayer as a Christian breath through which Christians inhale and exhale in their relationship with God. Prayer is the Christian practice of obedience to God[2]. For our purposes, I would like to draw three aspects of prayer from Barth's theology.

First, Barth thinks of prayer as a Christian attitude of petition and penitence ${ }^{3}$. He emphasizes two kinds of Christian prayer of petition. In the first stance, it is the Christian confession of petition for God's forgiveness. The goal of petitive prayer is to acknowledge our weaknesses and limitation and the goal of penitence is for God's forgiveness. In this respect, Barth sees petition and penitence as two centers of Christian prayer. For example, the prayer of Pharisees has full of praise, but what is lacking is their attitudes of confession and repentance ${ }^{4}$. Building on the Lord's Prayer, which teaches, "Forgive us our trespasses" (Matt. 6:12a), Barth emphasizes that the Christian prayer of petition and pertinence is important for asking God's forgiveness 5 . To pray in this sense means to renounce weaknesses and imperfections about ourselves and to admit ourselves to God. The end goal of such prayer is not to change God, but to change Christians to the extent that they would repent their sinful natures and renew their mind for transformation[3].

1 Terry C. Muck, "Introduction," in Rita M. Gross and Terry Muck, eds, Christians Talk about Buddhist Meditation and Buddhists Talk about Christian Prayer (New York: Continuum, 2003): 7-11 at 9. It is important to note about the editors of this book: Gross is a practicing Buddhist scholar, and Muck is a practicing Christian scholar, p. 9.

2 Karl Barth, Church Dogmatics: The Doctrine of Creation, III.3. eds. W.G. Bromiley and T.F. Torrance (Edinburgh: T\&T Clark, 1960$), 265$.

3 Ibid., 267.

4 Ibid., 267.

5 lbid., 268. 
The second kind of Christian petition is a matter of an asking a seeking and a knocking, a desiring and a requesting presented to $\mathrm{God}^{6}$. This kind of prayer is grounded in Matthew 7:7-8. In this text, Jesus not only urges His disciples, but also gives them promise. He said to His disciples, "ask, it will be given to you; seek and you will find; knock and the door will be opened. For everyone who asks receives; he who seeks find; and to whom knocks, the door will be opened." It is in this sense that Christian prayer is not asking for God's forgiveness, but asking for God's blessings, believing that God is the giver of all good gifts. This second kind of prayer is more common to many Christians. Many Christians think of prayer mainly as asking and seeking something of God. However, there are two kinds of Christians who expresses their desires to God. One kind of Christians asks God for what they want, while others ask God for what they need[4].

Finally, Barth defines Christian prayer as a form of adoration and praise of God ${ }^{7}$. Barth's sense of Christian praise is not just a weekly worship of God on Sunday, rather a daily adoration of God. Here I find Barth's sense of prayer as praise contradictory, yet complimentary to the first two forms of prayer as petition and penitence. The first two forms of prayer enable Christians to be the receivers of forgiveness and gift from God, while the second form of prayer enables Christians to be the giver of praise to God. In other words, God is the giver and the Christian are the receivers in the context of the first two forms of prayer, and the Christian are the givers and God is the receiver of praise from the Christian[5]. The purpose of prayer is not only to ask and seek something from God, but also to offer something, that is praise, to God. Building on the first and last line of the Lord's Prayer ("hollowed be thy name; for thine is the kingdom, the power and the glory for ever and ever"), Barth insists that Christian prayer begins and ends with praise ${ }^{8}$.

Barth also indicates the reason why we must praise God. He believes that we praise God for His daily providence. In thinking of God's daily providence of care and provision, it is essential for Christians to praise God from their hearts 9 . We must praise God for who He is (God is creator, redeemer and protector), for what He has done and is doing. In line with Barth, but going beyond him, I argue that our praise of God flows from joy and gratitude[6]. Our grateful heart flows from our contentment with what God has done and is doing for us. Put together, there is no sincere praise of God without grateful heart, and no gratitude without being content with God's daily providence.

Put the three form of Christian prayer, what is missing in Barth's theology of prayer is the Christian practice of meditation. Does Barth treat prayer as a synonym of meditation? Or does Barth not think of meditation as the necessary practice of Christians? If there is no meditation in the lives of Christians, would prayer not treat God as the mere listener to the voices of Christians? I believe that prayer is a two-way communication. God listens and speaks to us. This means meditation has a role in Christian prayer. I will now turn my attention to the Buddhist teaching and practice of mediation and explore some possible ways of exchanges for Christian-Buddhist dialogue on meditation[7].

\section{Meditation in the theology of Buddhism}

My aim is not to explore various forms of the Buddhist practice of meditation, but rather to explore the goals of Buddhist meditation. Considering the latter, I would like to discuss two goals of the Buddhist meditation and to propose how Buddhist meditation could enrich the Christian practice of prayer as a twoway communication with God.

First, the goal of Buddhist meditation is to purify or cultivate one's mind. This is understandable when we look at the summary of the Buddhist dharma. That is "not to commit evil, but to do good and to meditate one's mind ${ }^{10}$. Since the outward nature of immoral action comes from the inward wrong choice, the Buddha emphasizes the third line-meditating or purifying one's mind. Since the mind is the source of tahna (uncontrollable desire for evil), the Buddha emphasizes the need of purifying the mind ${ }^{11}$. The doctrine of meditation is grounded in the eightfold path of Buddhism[8]. The Buddhist doctrine of eightfold path can be summarized into three main principles-morality, wisdom and meditation. Morality (the ethics of right speech and right action and others) and wisdom (right knowledge) flow from meditation (cultivating our mind).

6 Ibid., 286.

7 lbid., 268.

$8 \mathrm{lbid} ., 268$.

9 lbid., 268.

10 Masao Abe, "The Problem of Evil in Christianity and Buddhism," in Buddhist-Christian Dialogue: Mutual Renewal and Transformation, eds. Paul Ingram and Frederick Streng (Honolulu: University of Hawaii Press, 1986), 140-150 at 141.

11 For full account of evil and sin Christian and Buddhist Perspectives, see my article, David Thang Moe, "Sin and Evil in Christian and Buddhist Perspectives: A Quest for Theodicy," in Asia Journal of Theology, Vol. 29. No. 1 (April 2015): 22-46. 
I would like to regard "cultivating the mind" as a source for an inner liberation of the self or liberating the self. Unlike Christians, Buddhists do not believe in outside-salvation, that is salvation by the grace of Christ. Rather they believe in the inside or selfsalvation, liberation by self-work of meditation. Too often we think of the Buddha as a savior for Buddhists. That is not true. Rather the Buddha is the example of moral guide and meditative teacher for their liberation. It is through his spiritual practice of meditation that the Buddha is liberated or enlightened and finds the Four Noble truth- (the truth of the reality of suffering; the truth of the cause of suffering; and the end of suffering and the path that leads to enlightenment of liberation). To liberate from suffering caused by desire, Buddhists, the followers of the Buddha, must cultivate their minds. In this sense, the Buddhist spiritual practice of meditation is soteriologically oriented ${ }^{12}$.

The second goal of meditation is for the physical liberation of the self. I would like to call this "a theology of body." This goal is most manifest in the Buddhist practice of yoga. Yoga meditation is the practice of allowing the mind to become quiet and the body to relieve anxiety. In this sense, yoga meditation is beneficial to both the mind and the body. Many Buddhists practice yoga as a way of both mental and physical health by relieving stress and stretching body[9]. Ultimately yoga is a means for body heath. The meditative practice of yoga deepens Buddhists their wisdom of good health, compassion for the suffering ones and insight of the ethics. In short, the goal of yoga and meditation is the extension of the search for meaning in self and the attainment of liberation from inner desire and worldly suffering ${ }^{13}$. I will develop these two goals of Buddhist practice of mediation in dialogue with Barth's theology of Christian prayer.

\section{Are the Buddhist Meditation and Christian Prayer Com- patible?}

The answer is yes, but we must be aware that the Buddhist spiritual practice and the Christian spiritual practice of prayer are fundamentally different from each other. As a non-theistic religion, the Buddhist mediation is not addressed to God, or even to the Buddha, whereas Christians' theistic prayer is addressed to God. Moreover, another contrast is that the "Buddhist practice of meditation is non-verbal, a silent noting of the breath, whereas the Christian prayer is verbal, filled with words addressing God ${ }^{14}$. Yet, I find the Buddhist practice of meditation as a way of liberating the self or self-consciousness persuasive for speaking of the goal of Christian prayer as liberation. Barth defines "Christian faith as liberation-liberation not in an outward sense of social justice, but in a liberative sense of an inward enlightenment ${ }^{15}$. Barth does not define prayer as liberation because he sees prayer as a one-way communication with God.

Barth's theology of prayer is one-sided in a way that God is always on the listening side and Christians on the speaking side. I must argue that true prayer must be practiced as a two-way communication between God and Christians. This does not mean that God should also pray so that Christians would listen to Him. Rather the point I want to make is: prayer is a time for mutual relationship between God and Christians. There is a time for Christians to speak to God; and God listens to Christians. There is a time for God to speak to Christians and Christians listen to Him. It is considering the latter that I would like to value the Buddhist practice of meditation as fulfillment for the Christian spiritual practice of prayer. Prayer and meditation should always go hand in hand. It is stressed that prayer is not a synonym of meditation, but rather they are mutually related. Prayer allows Christians to speak to God, and God listens. Meditation enables God to speak to the Christians and the Christian listen. In other words, meditation allows Christians to discern God's voice (God speaks). Prayer without meditative listening to God's voice is not transformative. Christians always focus on one aspect of prayer.

If prayer is not merely to request God for something, but to discern His will, it is imperative for Christians to allow God to speak to them through meditation. This is precisely because the goal of prayer with meditation is not to transform the mind of God, but rather to transform the mind of Christians into the likeness of Christ (Rom. 8:29; 12:2) by the power of the Spirit. As I have noted above, the goal of Buddhist practice of meditation is liberating the self and cultivating the mind so that they live morally in their right relationship with their fellow humans and other creatures. Their spiritual meditation of cultivating the minds transforms their moral behaviors. The Bible tells us that Christians should also cultivate their minds and hold fast to what is good in God's sights. There are three good examples of Bible verses that focus on the relationship between the meditative cultivation of minds and the moral lives of the disciples of Christ.

12 Kenneth K. Tanaka, "Christian Prayer Seen from the Eye of a Buddhist," in Rita M. Gross and Terry Muck, eds, Christians Talk about Buddhist Meditation and Buddhists Talk about Christian Prayer (New York: Continuum, 2003): 101-108 at 102-104.

13 http://buddhism-guide.com/buddhism/yoga.htm(accessed November 12, 2017).

14 Rita M. Gross, "Meditation and Prayer: A Comparative Inquiry," in Rita M. Gross and Terry Muck, eds, Christians Talk about Buddhist Meditation and Buddhists Talk about Christian Prayer (New York: Continuum, 2003): 88-100 at 89.

15 Barth, $C D$, III.3., 247. 
First, Paul urges Christians in Thessalonica "to hold fast to what is good and moral and to abstain from every form of evil" (1Thess. 5:21-22). Second, Peter urges the disciples of Christ to prepare for their minds for moral or holy action as embodying God's holiness (1Pet. 1:13-16). Third, the Lord's Prayer says, "lead us not into temptation, but deliver us from evil" (Matt. 6:13). These three Bible verses echo the summary of Buddhist dharma: "not to commit evil, but to do good and to meditate one'smind." As I said, the Buddha emphasizes cultivating the mind for the goals of doing the good and avoiding the evil. Indeed, when they cultivate their minds, Buddhists do not expect the help of the Buddha. By contrast, when Christians cultivate their minds, they expect the help of Jesus. Yet, the analogy I am drawing is the goal of meditation. From a Buddhist perspective, the goal of meditation or the cultivation of their minds is liberation from evils or immoral actions. From a Christian perspective, meditation is an ontological encounter with God and discerning His will for holy living and liberation from evils.

Sometimes in our prayer to God, we want to impose our will on God rather than discerning God's will for us. This is because we speak to God without listening to Him. When we meditate, we allow God to speak to us. It is in this context that we may define meditation as an encounter with God. When we truly encounter with God, we surrender our limitations to God. This is what Barth calls "the prayer of penitence," though he never talks about meditation. Especially Orthodox Christians think of meditation as an encounter with God and experiencing the holiness of God. This means that the ultimate goal of such meditation is to realize who God is and what we $\operatorname{are}^{16}$. It is through the meditative practice that we experience God's revelation. Barth defines God's revelation as a dialectical sense: God reveals His nature of love and holiness on the one hand, and God reveals our sinful nature on the other hand. Barth speaks of the analogy of God's revelation. He famously said, "As a ray of sunshine reveals dirt in a dark room, so does Jesus reveal our sins or immoral acts and thoughts in our minds (the factories of idols in the words of Calvin ${ }^{17}$ Precisely because of this, Barth defines "faith as liberation ${ }^{18}$."

For Barth, God's revelation and Christian faith are inseparable. Faith is not only a relationship with God, but it is also a liberation. The "God who reveals Himself through Himself (Jesus Christ ${ }^{19}$ )" to the world is the God who reveals to Christians through their faith. Likewise, faith and meditative prayer are inseparable for the process of Christian liberation. Faith is the result of the dialectical combination of God's gift and Christian response to
God's salvation, while the meditative prayer is the spiritual duty of Christians

for their ontological encounter with God. Faith without meditative prayer is not only blind, but also enslaved to the evil thoughts and immoral actions. If faith is liberation (knowing who God is and who we are), then Christians must necessarily take meditative prayer as the spiritual duty. Objectively, God encounters with us in Christ, ontologically we must also encounter with God through the spiritual practice of meditation and prayer.

\section{Conclusion}

\section{Meditative Prayer as an Inner Liberation}

In this paper, I have explored three characteristics of Barth's Christian theology of prayer and two characteristics of Buddhist practice of meditation. I have also demonstrated some divergences and convergences of the Christian practice of prayer and the Buddhist practice of meditation. Building on the common ground of the ultimate goals of prayer and meditation as liberation, I have suggested that the Christian spiritual practice of prayer and the Buddhist spiritual practice of meditation are compatible with each other for a better understanding and knowledge of God, ourselves, our neighbors and the world. Too often Christians think of prayer as a one-way communication with God, imposing their will and desire on God. I have argued against such imposive prayer and have suggested that Christians should learn the Buddhist practice of meditation as an analogy for Christian' two-way communication with God by cultivating their minds and discerning God's nature of holiness and His ethical will for Christians and for the world.

It is fair to argue that the goal of Christian prayer is not to change the mind of God, but rather to change/liberate their minds. Paul reminds Christians in Rome to be transformed by renewing their minds (Rom. 12:2). Cultivating the minds leads to the holy and virtuous living. Moreover, Paul urges Roman Christians to offer their bodies as living sacrifices-holy and pleasing to God (12:1). Paul understands that the bodies and minds are inseparable in our healthy relationship with God. Analogously, Buddhists understand the values of both holy minds and moral bodies and thus the goal of meditation is to cultivate the minds and to heal bodily stress. Too often some Christians concentrate only on one aspect of spiritual healing. Christians must address the whole person in all their needs because God is concerned with the healing of the whole persons-mind and body-without separating the two. If so, Christians should learn from the Buddhist practice of mediation as an analogy for healing and liberating their bodies and minds.

16 Kallisto Ware, "The Power of the Name: The Function of the Jesus Prayer," in Cross Currents, Vol. 24. No. 2-3 (Summer-Fall 1974): 184203.

17 Karl Barth, Church Dogmatics: The Doctrine of Reconciliation, IV.2" see the concept of sin, 403.

18 Barth, $C D$, III.3., 247.

19 Karl Barth, Church Dogmatics: The Doctrine of the Word of God, I.1, trans. G.W. Bromiley and T.F. Torrance (Edinburgh: T\&T Clark, 1936), 296. 
In God's objective relationship with us in Christ, the goal is to liberate us, and in our ontological encounter with God through the meditative prayer, the goal is to liberate us into the likeness of Christ by the power of the Holy Spirit. Thus, true liberation is always an objective (God's relationship with us) and an ontological event (our spiritual encounter with God) in inter-communication between God and Christians and Buddhists.

\section{References}

1. Masao A (1986) The Problem of evil in christianity and buddhism. In: Paul Ingram and Frederick Streng (Eds.), Buddhist-Christian Dialogue Mutual Renewal and Transformation, University of Hawaii Press, Honolulu, Hawaii, pp. 140-150.

2. Barth, Karl (1936) Church Dogmatics: The Doctrine of the Word of God, trans. GW Bromiley, Torrance TF (Eds.), Edinburgh, Scotland.

3. Church Dogmatics (1960): The Doctrine of Creation. III.3.

4. Church Dogmatics (1969): The Doctrine of Reconciliation. IV.2.
5. Rita MG (2003) Meditation and Prayer: A Comparative Inquiry." In: Rita M Gross, Terry Muck (Eds.), Christians Talk about Buddhist Meditation and Buddhists Talk about Christian Prayer. Continuum, New York, USA, pp. 88-100.

6. David Thang M (2015) Sin and Evil in Christian and Buddhist Perspectives: A Quest for Theodicy. Asia Journal of Theology 29(1): 2246.

7. Terry CM (2003) Introduction. In: Rita M Gross, Terry Muck (Eds.), Christians Talk about Buddhist Meditation and Buddhists Talk about Christian Prayer. Continuum, New York, USA, pp. 7-11.

8. Kenneth KT (2003) "Christian Prayer Seen from the Eye of a Buddhist". In: Rita M Gross, Terry Muck (Eds.), Christians Talk about Buddhist Meditation and Buddhists Talk about Christian Prayer. Continuum, New York, USA, pp. 101-108.

9. Kallisto W (2017) The "Power of the Name: The Function of the Jesus Prayer." In Cross Currents, (Summer-Fall 1974): 24(2-3): 184-203.

\section{Your next submission with Juniper Publishers} will reach you the below assets

- Quality Editorial service

- Swift Peer Review

- Reprints availability

- E-prints Service

- Manuscript Podcast for convenient understanding

- Global attainment for your research

- Manuscript accessibility in different formats

( Pdf, E-pub, Full Text, Audio)

- Unceasing customer service

Track the below URL for one-step submission

https://juniperpublishers.com/online-submission.php 